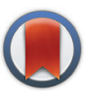

CrossMark \&lick for updates

Cite this: Dalton Trans., 2016, 45 14719

Received 27th April 2016, Accepted 31st May 2016

DOI: $10.1039 / c 6 d t 01648 k$

www.rsc.org/dalton

\section{Small-molecule activation at Au(III): metallacycle construction from ethylene, water, and acetonitrile $\uparrow$}

\author{
Marte Sofie Martinsen Holmsen, ${ }^{a}$ Ainara Nova, ${ }^{b}$ David Balcells, ${ }^{b}$ Eirin Langseth, $\star^{a}$ \\ Sigurd Øien-Ødegaard, ${ }^{a}$ Eline Aasen Tråseth, ${ }^{a}$ Richard H. Heyn ${ }^{c}$ and Mats Tilset ${ }^{\star a, b}$
}

Incorporation of the simple, readily available, building blocks ethylene, water and acetonitrile into Au(tpy) $\left(\mathrm{OCOCF}_{3}\right)_{2}$ (tpy $=2$ - $(p$-tolyl)pyridine) in a one-step reaction leads to high yields of a new 6 -membered ring gold(III) metallacycle complex. The metallacycle has been characterized spectroscopically and crystallographically, and the mechanism of its formation has been investigated with the aid of DFT calculations.

\section{Introduction}

The functionalization of alkenes has great practical and economic value in catalysis, and as the simplest of such building blocks, ethylene is of particular interest. ${ }^{1}$ Gold is known for its ability to $\pi$-coordinate and thereby activate alkenes and alkynes towards nucleophilic attack, which is considered to be a key step in gold catalysis. ${ }^{2-8}$ However, there are only scarce reports of $\mathrm{Au}(\mathrm{III})$-mediated functionalization of the simplest olefin, ethylene. One important example was provided by Atwood and co-workers (Scheme 1, top), ${ }^{9}$ who demonstrated that ethylene and propylene could be functionalized stoichiometrically at the $\mathrm{Au}(\mathrm{III})$ complex $\mathrm{Au}$ (bipy) $\mathrm{Cl}_{2}{ }^{+}$(bipy $=$ $2,2^{\prime}$-bipyridine) in water to furnish $\mathrm{Au}(\mathrm{III})$ hydroxyalkyl products that were observed in solution by ${ }^{1} \mathrm{H}$ NMR spectroscopy but not isolated. Reactions of ethylene and propylene with $\mathrm{HAuCl}_{3}$ and $\mathrm{AuCl}_{3}$ (tppts) (tppts $=3,3^{\prime}, 3^{\prime \prime}$-phosphanetriyltris(benzenesulfonic acid) trisodium salt) led to $\mathrm{Au}(\mathrm{III})$ hydroxyalkyl species, which upon heating underwent gold reduction to the metal with concomitant formation of organic oxygenated products (alcohols, aldehyde or ketone). ${ }^{9}$ More recently, Bochmann and co-workers (Scheme 1, bottom) ${ }^{10}$ showed that ethylene slowly undergoes a formal insertion into the

\footnotetext{
${ }^{a}$ Department of Chemistry, University of Oslo, P.O. Box 1033 Blindern, N-0315 Oslo, Norway.E-mail: mats.tilset@kjemi.uio.no

${ }^{b}$ Centre for Theoretical and Computational Chemistry (CTCC), Department of Chemistry, University of Oslo, P.O. Box 1033 Blindern, N-0315 Oslo, Norway ${ }^{c}$ SINTEF Materials and Chemistry, P.O. Box 124 Blindern, N-0314 Oslo, Norway $\dagger$ Electronic supplementary information (ESI) available: Full experimental and computational details, characterization data, and spectra. CCDC 1443527 and 1443528. For ESI and crystallographic data in CIF or other electronic format see DOI: $10.1039 / \mathrm{c} 6 \mathrm{dt} 01648 \mathrm{k}$

¥Current address: SINTEF Materials and Chemistry, P.O. Box 124 Blindern, $\mathrm{N}-0314$ Oslo, Norway.
}

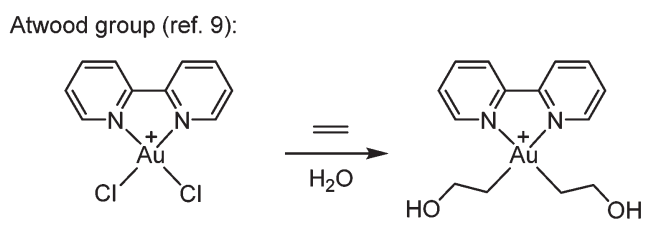

Bochmann group (ref. 10):
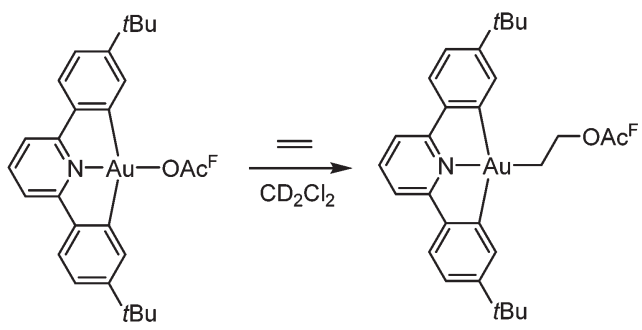

Scheme 1 Reactions of ethylene at $\mathrm{Au}(\mathrm{III})$ complexes $\left(\mathrm{OAC}^{\mathrm{F}}=\mathrm{OCOCF}_{3}\right)$.

$\mathrm{Au}-\mathrm{OAc} \mathrm{F}^{\mathrm{F}}$ bond trans to the pyridine-N in a diarylpyridine CNC pincer complex to yield an Au(III) acetoxyalkyl complex $\left(\mathrm{OAc}^{\mathrm{F}}=\mathrm{OCOCF}_{3}\right)$.

Our group recently reported a combined experimental and computational study of the formal insertion of ethylene into an $\mathrm{Au}-\mathrm{O}$ bond of $\mathrm{Au}(\mathrm{tpy})\left(\mathrm{OAc}^{\mathrm{F}}\right)_{2}$ (1; tpy = 2- $(p$-tolyl $)$ pyridine; Scheme 2, top). ${ }^{11}$ Selective insertion into the $\mathrm{Au}-\mathrm{O}$ bond trans to $\mathrm{N}$ of the chelating tpy ligand furnished $\mathrm{Au}(\mathrm{tpy})-$ $\left(\mathrm{CH}_{2} \mathrm{CH}_{2} \mathrm{OAc}^{\mathrm{F}}\right)\left(\mathrm{OAc}^{\mathrm{F}}\right)$ (2). Although the trans to $\mathrm{C}$ coordination site is kinetically more accessible, the trans to $\mathrm{N}$ insertion product is thermodynamically favoured and is formed by nucleophilic attack by free ${ }^{-} \mathrm{OAc}^{\mathrm{F}}$ at the coordinated ethylene. This discovery led to further investigations, and herein we report that the coordinated and inserted ethylene molecule can undergo further functionalization due to the availability of the trans to $\mathrm{C}$ coordination site at $\mathrm{Au}$. 


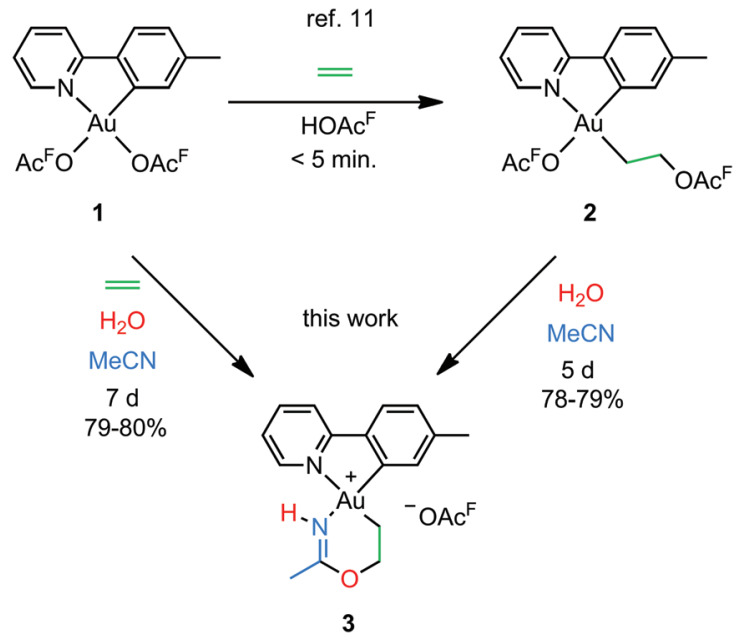

Scheme 2 Formal insertion of ethylene into an $\mathrm{Au}-\mathrm{O}$ bond of $\mathrm{Au}($ tpy $)\left(\mathrm{OAc}^{\mathrm{F}}\right)_{2}(1)^{11}$ and preparation of the metallacyclic $\mathrm{Au}(\mathrm{III})$ complex 3 from 1 and 2 (this work); $\left(\mathrm{OAc}^{\mathrm{F}}=\mathrm{OCOCF}_{3}\right)$.

\section{Results and discussion}

\section{Synthesis and characterization}

An attempt to crystallize a product mixture containing $\mathbf{2}$ from acetonitrile led instead to the isolation of small quantities of a new crystalline complex. Examination of these crystals by single-crystal X-ray diffraction revealed that the new complex was a $\mathrm{Au}$ (III) metallacycle 3 (Scheme 2, lower part). Synthesis of larger quantities of 3 in about $80 \%$ yield was possible simply by stirring 2 in wet acetonitrile for 5 days at ambient temperature. Alternatively, 3 can be obtained in comparable yields by dissolving $\mathbf{1}$ in acetonitrile and adding water and ethylene. Thus, an efficient synthetic protocol has been developed wherein the three small, readily available building blocks ethylene, water, and acetonitrile are incorporated into the $\mathrm{Au}(\mathrm{III})$ metallacycle complex 3 in just one step.

The molecular structure, based on the single-crystal X-ray analysis, clearly indicated a complex which contained a new 6-membered chelate ring. Although the X-ray data and the refined structure were of excellent quality, we were concerned about the even slightest possibility of a $\mathrm{NH} v s$. O misassignment, ${ }^{12,13}$ and sought additional and independent verification of the connectivity seen in the structure. Thus, the three alternatives 3, 4, and 5 in Scheme 3 were initially considered. The 6-ring chelates in these alternatives are formally derived from $\mathrm{Au}$, ethylene, acetonitrile, and one $(3,4)$ or two (5) equiv.
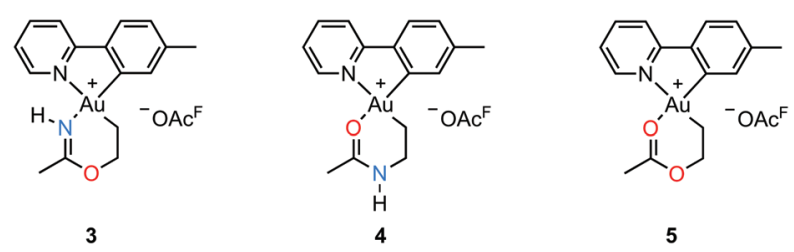

Scheme 3 Possible structures of the metallacyclic Au(III) complex. of water. However, involvement of reagents arising from a (possibly gold) catalyzed hydrolysis of acetonitrile, or from impurities inadvertently present in this solvent, must also be considered.

By positive-ion high resolution mass spectrometry (HRMS), the parent ion at $\mathrm{m} / \mathrm{z}=451.1068$ established the elemental composition $\mathrm{C}_{16} \mathrm{H}_{18} \mathrm{AuN}_{2} \mathrm{O}$ for the cation (calcd $\mathrm{m} / \mathrm{z}=$ 451.1084), in accord with the presence of one $\mathrm{N}$ and one $\mathrm{O}$ atom in the chelate ring. This composition, which eliminates alternative 5, was corroborated by elemental analysis. Support for the formulation of the $\mathrm{N}, \mathrm{O}$-containing chelate $\mathbf{3}$ was obtained by ${ }^{1} \mathrm{H}^{-15} \mathrm{~N}$ HMBC NMR spectroscopy. In the spectrum, signals arising from two different $\mathrm{N}$ atoms are clearly observed. One signal at $\delta\left({ }^{15} \mathrm{~N}\left\{{ }^{1} \mathrm{H}\right\}\right)=-212$ arises from the chelate $\mathrm{NH}$ and correlates with the broadened ${ }^{1} \mathrm{H}$ signal of the $\mathrm{NH}$ group at $\delta\left({ }^{1} \mathrm{H}\right)=10.28$ and with the signal from the metallacycle methyl group at $\delta\left({ }^{1} \mathrm{H}\right)=2.51$, but not with the other protons of the metallacycle. The other ${ }^{15} \mathrm{~N}$ signal at $\delta\left({ }^{15} \mathrm{~N}\left\{{ }^{1} \mathrm{H}\right\}\right)=$ -129 arises from the $\mathrm{N}$ atom in the tpy ligand and has a correlation with the signal arising from the $\mathrm{CH}$ proton $\alpha$ to the pyridyl-N atom at $\delta\left({ }^{1} \mathrm{H}\right)=9.33$. The ${ }^{19} \mathrm{~F}$ NMR spectrum shows only one signal, arising from the ${ }^{-} \mathrm{OAc}^{\mathrm{F}}$ anion. So as to further unambiguously distinguish between alternatives 3 and 4 , a NOE experiment was performed. The ${ }^{1} \mathrm{H}^{-}{ }^{1} \mathrm{H}$ NOESY spectrum shows a clear NOE interaction between the NH proton at $\delta$ 10.28 and the $\mathrm{CH}$ proton at $\delta 9.33$. These $\mathrm{H}$ atoms are therefore in close proximity, supporting the crystallographic analysis and verifying that $\mathbf{3}$ does indeed represent the structure of the metallacycle.

An ORTEP plot of the molecular structure of 3 is shown in Fig. 1, with selected bond distances and angles. The $\mathrm{Au}(\mathrm{III})$ centre has the expected square planar geometry. The deviation of the $\mathrm{C} 9-\mathrm{Au}-\mathrm{N} 1$ bond angle in the tpy chelate from 90 to $80.60(10)^{\circ}$ is typical, and the Au-ligand distances Au1-N1, $\mathrm{Au} 1-\mathrm{C}$, and $\mathrm{Au} 1-\mathrm{C} 4\left(\mathrm{sp}^{3}\right)$ are within the ranges that have previously been observed for the related complexes $\mathrm{Au}\left(\right.$ tpy) $\mathrm{Me}_{2},{ }^{14}$ $\mathrm{Au}($ tpy $)\left(\mathrm{CH}_{2} \mathrm{CH}_{2} \mathrm{OAc}{ }^{\mathrm{F}}\right)\left(\mathrm{OAc}^{\mathrm{F}}\right),{ }^{11}$ and $\mathrm{Au}($ tpy $)\left(\mathrm{CH}_{2} \mathrm{CH}_{2} \mathrm{OCH}_{2} \mathrm{CF}_{3}\right)$

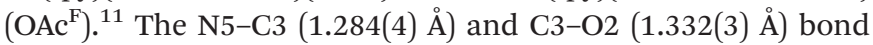
distances are consistent with the corresponding average $\mathrm{N}=\mathrm{C}$ $\left(\begin{array}{ll}1.282 & \AA\end{array}\right)$ and $\mathrm{C}-\mathrm{O} \quad(1.325$ Å) in $\mathrm{Pt}(\mathrm{II})$ imino ether complexes. ${ }^{15-22} \|$ These distances are, however, distinctly different from the distances in a $\left[(\mathrm{tpa}) \mathrm{Rh}^{\mathrm{III}}\right]^{2+}(\mathrm{tpa}=N, N, N$-tri (2-pyridylmethyl)amine) analogue to 3 , in which the corresponding $\mathrm{N}-\mathrm{C}$ and $\mathrm{C}-\mathrm{O}$ bond distances are 1.245(19) and 1.374 (17) $\AA$, respectively. ${ }^{23}$ The directionality of the N5 $\cdots$ O1A interaction between the $\mathrm{NH}$ of the 6-membered ring and the nearest $\mathrm{O}(\mathrm{O} 1 \mathrm{~A})$ of the trifluoroacetate anion suggests the presence of a hydrogen bond; in fact, the final refinement shows a

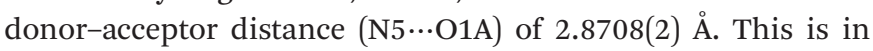
excellent agreement with the proposed structure 3 . The crystal structure of 3 is monoclinic, but with $\beta=90^{\circ}$. In addition, it is twinned via a twofold rotation about the crystallographic $a$

ๆ See ESI pages S5, S13, and S14 $†$ for details.

|| No structural examples of Au imino ethers were found via SciFinder. 


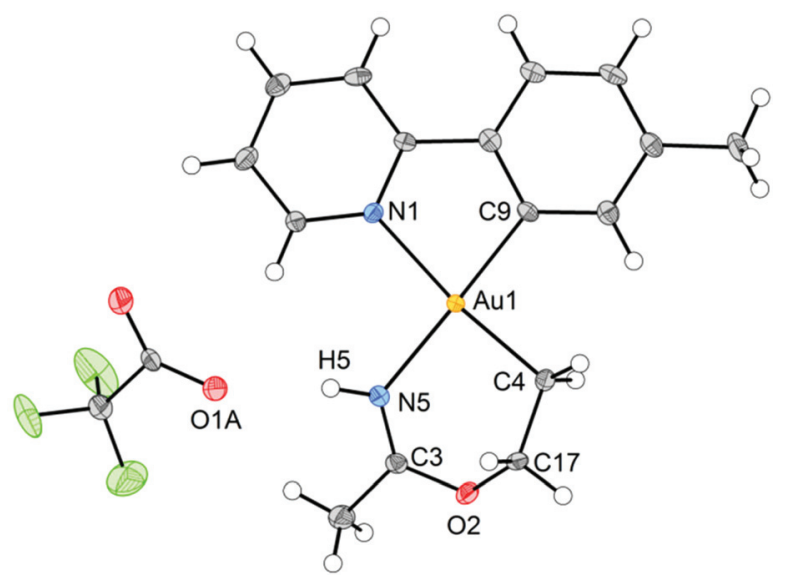

Fig. 1 ORTEP drawing of $\mathrm{Au}(\mathrm{III})$ complex 3, with $50 \%$ probability ellipsoids. Selected bond distances (Å), angles, and torsional angles ( ${ }^{\circ}$ ): Au1C4, 2.042(3); Au1-C9, 2.019(3); Au1-N1, 2.126(2); Au1-N5, 2.092(3); C3-N5, 1.284(4); C3-O2, 1.332(3); C17-O2, 1.449(4); C4-C17, 1.510(4); O1A N5, 2.8708(2); C4-Au1-C9, 92.39(12); C4-Au1-N5, 89.54(11); C9Au1-N1, 80.60(10); N1-Au1-N5, 97.43(9); C4-Au1-N1, 172.99(11); C9Au1-N5, 174.24(12); C3-O2-C17-C4, -70.8(4); Au1-C4-C17-O2, 60.2(3); Au1-N5-C3-O2, 26.5(5); C17-O2-C3-N5, 21.8(5).

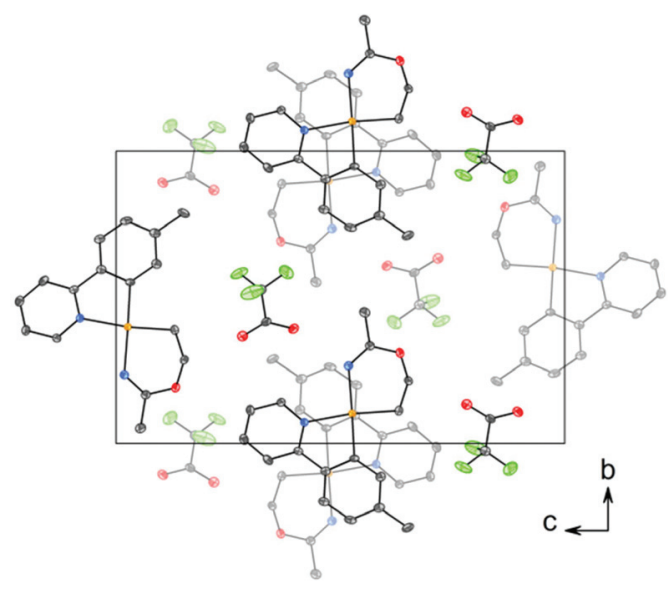

Fig. 2 Packing diagram of structure 3 viewed along the a axis, showing stacking between the tpy ligands. The thermal ellipsoids are displayed at $50 \%$ probability, and $\mathrm{H}$ atoms are omitted for clarity.

axis. The structure displays parallel displaced $\pi-\pi$ stacking along the $a$ direction, and the distance between the intersecting planes of the tpy ligands alternates between 3.42 and 3.44 ^ (Fig. 2).

DFT calculations were performed on the cations of 3,4 , and 5 in order to further assist with the verification of the structure. Gratifyingly, comparisons of the crystallographic data with the optimized structures showed that the average r.m.s. deviations of the atomic positions were considerably smaller for 3 (average deviation $0.015 \AA$ ) than for $4(0.022 \AA)$ and $\mathbf{5}$ $(0.032 \AA)$, lending further support for the structural assignment.
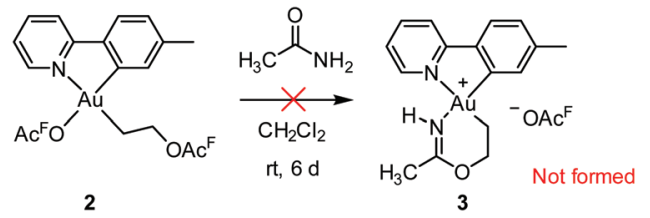

(A)
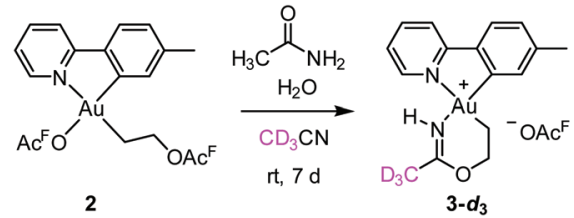

(B)

Scheme 4 Potential role of acetamide in the formation of 3 .

\section{Mechanistic studies by experiment and DFT calculations}

Initial mechanistic experiments probed whether a goldmediated or gold-catalyzed hydrolysis of acetonitrile to form acetamide might be involved in the process (Scheme 4). First, no formation of $\mathbf{3}$ was seen when $\mathbf{2}$ was treated with only acetamide in $\mathrm{CH}_{2} \mathrm{Cl}_{2}$ (Scheme $4 \mathrm{~A}$ ). Second, the reaction of 2 with wet acetonitrile- $d_{3}$ in the presence of acetamide led to the generation of $\mathbf{3}-\boldsymbol{d}_{\mathbf{3}}$ and a minor amount of $\mathbf{3}$ as inferred by integration of the metallacycle-methyl resonance at $\delta 2.51$ in the ${ }^{1} \mathrm{H}$ NMR spectrum (Scheme 4B). These experiments suggest that acetonitrile, and not acetamide, is the main reactant in the formation of the metallacycle.

Scheme 5 shows a possible mechanism for the formation of 3. The unobserved cationic ethylene complex 6 is generated from either 1 or 2 , in agreement with our previous findings. ${ }^{11}$ The hydroxyethyl complex 7 is formed from 2 after nucleophilic attack by water, by analogy with Atwood's study, ${ }^{9}$ and parallel to reaction of trifluoroethanol with 2, which proceeds via 6 yielding 10. ${ }^{11}$ Acetonitrile substitution for the ${ }^{-} \mathrm{OAc}^{\mathrm{F}}$ anion of 7 at the kinetically most accessible position ${ }^{11}$ trans to tpy-C furnishes a crucial intermediate $\mathbf{8}$, which undergoes cyclization by an intramolecular nucleophilic attack of the hydroxyethyl-O atom on the nitrile-C atom of acetonitrile, analogous to the alcoholysis of $\mathrm{Pt}(\mathrm{II})$-coordinated nitriles to provide $\mathrm{Pt}(\mathrm{II})$ imino ethers. ${ }^{20-22} \mathrm{An}^{-} \mathrm{OAc}^{\mathrm{F}}$ anion assisted proton transfer from $\mathrm{O}$ to $\mathrm{N}$ finally provides 3 . Close analogues of the putative intermediates 7 and 8 exist and support their mechanistic viability. The hydroxyethyl complex 7 is an analogue of $\mathrm{Au}($ tpy)Me(OTf) and $\mathrm{Au}($ tpy $) \mathrm{Me}(\mathrm{OAc})$; both have been structurally characterized as the pertinent stereoisomers with Me trans to $\mathrm{N} .{ }^{24}$ Complex 8 is closely related to $\left[\mathrm{Au}(\right.$ tpy) $\mathrm{Me}(\mathrm{NCMe})]\left[\mathrm{BF}_{4}\right](9)$ which has been prepared with the relevant stereochemistry at $\mathrm{Au}$ by bromide abstraction from AuBrMe(tpy) with $\mathrm{AgBF}_{4}$ in acetonitrile. ${ }^{25}$

The relative stability of all intermediates shown in Scheme 5 has been assessed by means of DFT calculations, which show that they are all accessible under the experimental conditions.§ The TS from $\mathbf{8}$ to $\mathbf{1 1}$ has also been computed (TS8-11,

$\S$ For an estimation of the transition state energies involved in the transformation of 1 to 7 , see ref. 11 . 

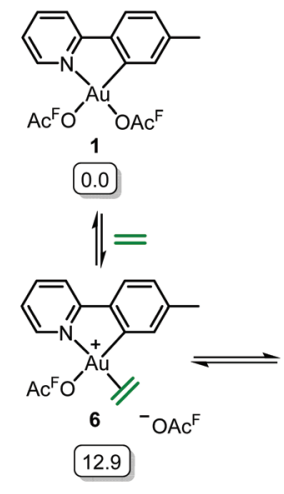

$\mathrm{HOAc} F$ \& $\mathrm{H}_{2} \mathrm{O}$

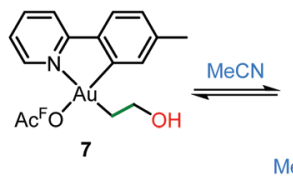

$-6.9$
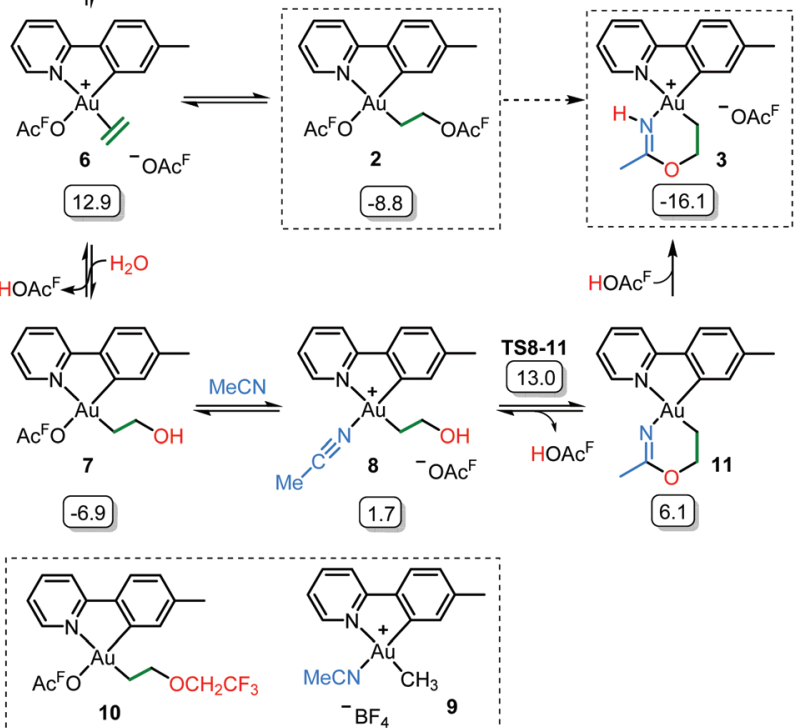

HOACF $\hat{\jmath}$

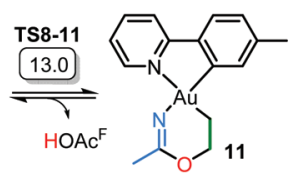

6.1

Scheme 5 Postulated reaction mechanism for the formation of 3 $\left(\mathrm{OAc}^{\mathrm{F}}=\mathrm{OCOCF}_{3}\right)$. Framed species have been characterized by $\mathrm{X}$-ray diffraction in either this or previous (ref. 11) work. Free energies obtained from DFT calculations in acetonitrile are given in $\mathrm{kcal} \mathrm{mol}^{-1}$.

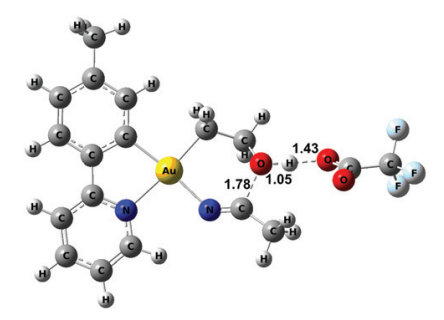

Fig. 3 Optimized geometry for TS8-11 with selected bond distances (Å).

Fig. 3) and it shows that cyclization is triggered by the deprotonation of the hydroxyl group by an external ${ }^{-} \mathrm{OAc}^{\mathrm{F}}$. This transition state is $13.0 \mathrm{kcal} \mathrm{mol}^{-1}$ higher than $\mathbf{1}$ and involves an effective energy barrier of $21.8 \mathrm{kcal} \mathrm{mol}^{-1}$ relative to 2 . The long experimental reaction time required for this transformation may be due to the existence of many equilibria, which are dependent on the different reactant concentrations.

\section{Concluding remarks}

An eventual reductive elimination from 3 would generate 2-methyl-2-oxazoline, with an important heterocyclic ring structure. Previously, 2-oxazolines have been prepared by Sawamura and coworkers ${ }^{26-28}$ by $\mathrm{Au}(\mathrm{I})$ catalyzed asymmetric aldol reactions

of isocyanides and aldehydes. Hashmi and coworkers more recently ${ }^{29,30}$ prepared oxazolines by $\mathrm{Au}(\mathrm{I})$-catalyzed cycloisomerizations of propargyl amides. Interestingly, it has been recently reported that cyclometallated $\mathrm{Au}(\mathrm{III})$ aryl-pyridine complexes may act as efficient catalysts for the three-component synthesis of propargylic amines from aldehydes, secondary amines, and alkynes, and of substituted oxazoles from $\mathrm{N}$-benzyl imines, alkynes, and acyl chlorides. ${ }^{31,32}$ The $\left[(\mathrm{tpa}) \mathrm{Rh}^{\mathrm{III}}\right]^{2+}$ analogue to 3 was synthesized in a two-step process by $\mathrm{H}_{2} \mathrm{O}_{2}$ oxidation of a coordinated ethylene, followed by reaction with acetonitrile and $\mathrm{NH}_{4} \mathrm{PF}_{6} \cdot{ }^{23}$ In this context, our one-step assembly of an oxazoline from an alkene, a nitrile, and water represents a new strategy with obvious possibilities in organic synthesis. ${ }^{33}$

In conclusion, the convenient and high-yield one-pot, fourcomponent assembly of a new cationic metallacyclic Au(III) complex has been described. In the process, the three small, readily available building blocks ethylene, water, and acetonitrile have been incorporated into one product. The transformation demonstrates that both of the potentially labile coordination sites in $\mathrm{Au}(\mathrm{tpy})\left(\mathrm{OAc}^{\mathrm{F}}\right)_{2}$ can be utilized - a fact that may be of importance for catalytic applications. The metallacycle is constructed in such a fashion that the high trans-effect (alkyl) end of the assembled chelate ligand occupies the position that is trans to the low trans-effect ( $\mathrm{N}$ donor) of the tpy supporting ligand, and vice versa.

\section{Experimental and computational section}

\section{General experimental methods}

Gold(III) complexes 1 and 2 were prepared by previously reported procedures. ${ }^{11,14}$ Distilled water was used. $\mathrm{CH}_{3} \mathrm{CN}$ and $\mathrm{CH}_{2} \mathrm{Cl}_{2}$ were purified using a MB SPS-800 solvent purifying system from MBraun. The gold(III) complexes studied here are not sensitive to air, so inert atmosphere was not utilized, except for the synthesis of 9 which is described in the ESI. $\dagger$ NMR spectra were recorded on Bruker Avance DPX200, AVII400, DRX500, AVII600 and AV600 instruments at ambient temperature. ${ }^{1} \mathrm{H}$ and ${ }^{13} \mathrm{C}$ spectra have been referenced relative to the residual solvent signals. ${ }^{19} \mathrm{~F}$ has been referenced to $\mathrm{CFCl}_{3}$ by using $\mathrm{C}_{6} \mathrm{~F}_{6}$ $\left(-164.9 \mathrm{ppm}\right.$ with respect to $\mathrm{CFCl}_{3}$ at $\left.0 \mathrm{ppm}\right)$ as an internal standard. The ${ }^{15} \mathrm{~N}$ chemical shifts have been calibrated using $\mathrm{MeNO}_{2}$ as an external standard at $0 \mathrm{ppm}$. The peaks in the ${ }^{1} \mathrm{H}$ NMR and ${ }^{13} \mathrm{C}$ NMR spectra were assigned by the aid of $2 \mathrm{D}$ NMR techniques such as HSQC, HMBC, COSY, NOESY, and ${ }^{1} \mathrm{H}-{ }^{15} \mathrm{~N}$ HMBC according to the numbering scheme shown below. Mass spectra (ESI) were obtained on a Micromass QTOF II spectrometer and a Bruker Daltronics maXisII spectrometer. Elemental analysis was performed by Microanalytisches Laboratorium Kolbe, Mülheim an der Ruhr, Germany.

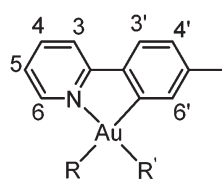


Preparation of $\left[\mathrm{Au}(\mathrm{tpy})(\mathrm{C}-\mathrm{N})^{+}\right]\left[{ }^{-} \mathrm{OCOCF}_{3}\right]$ (3) from 1. Au(tpy) $\left(\mathrm{OCOCF}_{3}\right)_{2}(50.1 \mathrm{mg}, 0.0847 \mathrm{mmol}, 1.0$ equiv.) was dissolved in acetonitrile $(3 \mathrm{~mL})$. Water $(10 \mu \mathrm{L}, 0.55 \mathrm{mmol}, 6.5$ equiv.) was added. Ethylene was bubbled through the solution at ambient pressure for two minutes, and the flask was sealed with a glass stopper. The reaction mixture was stirred at ambient temperature in the absence of light for 7 days. The reaction mixture was filtered and the volatiles were removed under reduced pressure furnishing 3 as a white solid $(38.1 \mathrm{mg}, 0.0675 \mathrm{mmol}$, $80 \%)$.

Preparation of $\left[\mathrm{Au}(\mathrm{tpy})(\mathrm{C}-\mathrm{N})^{+}\right]\left[{ }^{-} \mathrm{OCOCF}_{3}\right]$ (3) from 2. Au(tpy)$\left(\mathrm{CH}_{2} \mathrm{CH}_{2} \mathrm{OCOCF}_{3}\right)\left(\mathrm{OCOCF}_{3}\right)(50.1 \mathrm{mg}, 0.0809 \mathrm{mmol}, 1.0$ equiv. $)$ was dissolved in acetonitrile $(3 \mathrm{~mL})$. Water $(10 \mu \mathrm{L}, 0.55 \mathrm{mmol}$, 6.8 equiv.) was added. Ethylene was bubbled through the solution at ambient pressure for two minutes, and the flask was sealed with a glass stopper. The reaction mixture was stirred at ambient temperature in the absence of light for 5 days. The reaction mixture was filtered and the volatiles were removed under reduced pressure furnishing 3 as a white solid $(35.8 \mathrm{mg}$, $0.0634 \mathrm{mmol}, 78 \%) .{ }^{1} \mathbf{H}$ NMR $\left(600 \mathrm{MHz}, \mathrm{CD}_{2} \mathrm{Cl}_{2}\right): \delta 10.28$ (bs, $1 \mathrm{H}, \mathrm{NH}), 9.33\left(\mathrm{~d}, 1 \mathrm{H}, J=5.4 \mathrm{~Hz}, \mathbf{H}^{6}\right), 8.08(\mathrm{ddd}, 1 \mathrm{H}, J=$ 8.0, 7.5, 1.4 Hz, $\left.\mathbf{H}^{4}\right), 7.96\left(\mathrm{~d}, 1 \mathrm{H}, J=8.0 \mathrm{~Hz}, \mathbf{H}^{3}\right), 7.71(\mathrm{~d}, 1 \mathrm{H}$, $\left.J=7.7 \mathrm{~Hz}, \mathbf{H}^{3^{\prime}}\right), 7.58\left(\mathrm{ddd}, 1 \mathrm{H}, J=7.5,5.6,1.1 \mathrm{~Hz}, \mathbf{H}^{5}\right)$, 7.23-7.25 (m, 2H, $\mathbf{H}^{4^{\prime}}$ and $\left.\mathbf{H}^{6^{\prime}}\right), 4.34\left(\mathrm{~m}, 2 \mathrm{H}, \mathrm{OCH}_{2}\right), 2.73$ $\left(\mathrm{m}, 2 \mathrm{H}, \mathrm{AuCH}_{2}\right), 2.51$ (s, 3H, OCCH 3 ), 2.44 (s, 3H, $\mathrm{ArCH}_{3}$ ). ${ }^{13} \mathrm{C} \quad$ NMR $\left(150 \mathrm{MHz}, \mathrm{CD}_{2} \mathrm{Cl}_{2}\right): \delta \quad 175.2, \quad 161.7,149.8$, $142.4,142.3,142.0,141.9,131.2,129.4,126.0,124.9,120.2$, 66.5, 28.6, 22.0, 21.6. ${ }^{-} \mathrm{OCOCF}_{3}$ was not observed by ${ }^{13} \mathrm{C}$ NMR. ${ }^{15} \mathbf{N}\left\{{ }^{1} \mathbf{H}\right\}$ NMR $\left(600 \mathrm{MHz}, \mathrm{CD}_{2} \mathrm{Cl}_{2}\right): \delta-129(\mathbf{N}($ tpy $)),-212(\mathbf{N H}$, $|J|=78 \mathrm{~Hz}$ ), as observed by ${ }^{1} \mathrm{H}^{-15} \mathrm{~N}$ HMBC (see Fig. S12†).

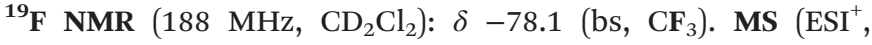

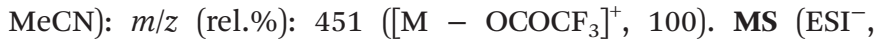

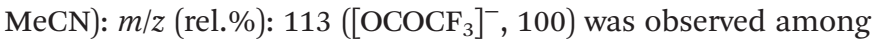
other unidentified peaks. HRMS $\left(\mathrm{ESI}^{+}, \mathrm{MeCN}\right)$ : Found: 451.1068; calcd for $\mathrm{C}_{16} \mathrm{H}_{18} \mathrm{AuN}_{2} \mathrm{O}$ : 451.1084 (+0.0016). HRMS (ESI $\left.{ }^{-}, \mathrm{MeCN}\right)$ : Found: 112.9859; calcd for $\mathrm{C}_{2} \mathrm{~F}_{3} \mathrm{O}_{2}$ : 112.9856 (-0.0003). Elemental analysis: Anal. Calcd for $\mathrm{C}_{18} \mathrm{H}_{18} \mathrm{AuF}_{3} \mathrm{~N}_{2} \mathrm{O}_{3}$ : C, 38.31; H, 3.22; N, 4.96. Found: C, 37.81; $\mathrm{H}, 3.19 ; \mathrm{N}, 4.59$.

\section{Computational details}

Calculations were carried out at the DFT level as implemented in the Gaussian09 software package. ${ }^{34}$ The hybrid PBE0+GD3 functional ${ }^{35,36}$ including Grimme's model for dispersion forces was used to optimize all geometries. This methodology was selected because previous studies have proven its solid performance in the modeling of $\mathrm{Au}(\mathrm{III})$ alkene complexes. ${ }^{8,11,37}$ $\mathrm{C}, \mathrm{H}, \mathrm{N}$ and $\mathrm{O}$ were described with the all-electron triple- $\zeta$ $6-311+\mathrm{G}^{* *}$ basis set, ${ }^{38,39}$ whereas Au was described with the Stuttgart-Köln basis set including a small-core quasi-relativistic pseudopotential. ${ }^{40,41}$ Geometries were fully optimized without any constraint. Vibrational frequencies were computed analytically to verify that the stationary points found were energy minima or transition states. All optimizations needed for the mechanism proposal were carried out in solvent (acetonitrile) using the SMD solvation model. ${ }^{42}$ Complexes 3,4 and
5 were optimized in gas phase with the aim of comparing their geometries with an X-ray crystal structure. Gibbs energies were obtained for $T=298.15 \mathrm{~K}$ and $p=1 \mathrm{~atm}$. In the bimolecular steps, these energies were corrected for the $1 \mathrm{M}$ standard state $(T=298.15 \mathrm{~K}$ and $p=24.465 \mathrm{~atm})$. Further computational details are given in the ESI. $\dagger$

\section{Acknowledgements}

We are grateful for financial support from the Research Council of Norway for funding provided through the Centre of Excellence for Theoretical and Computational Chemistry (CTCC; Grant 179568/V30) and for stipends to AN, EL and MSMH (Grants 185513/I30 and 221801/F20), and the Norwegian Metacenter for Computational Science (NOTUR; Grant nn4654k). DB also thanks the EU REA for a Marie Curie Fellowship (Grant CompuWOC/618303). This work was also supported by COST Action CM1205 CARISMA (Catalytic Routines for Small Molecule Activation).

\section{Notes and references}

1 M. Chiarucci and M. Bandini, Beilstein J. Org. Chem., 2013, 9, 2586-2614.

2 A. S. K. Hashmi, S. Schäfer, M. Wölfle, C. Diez Gil, P. Fischer, A. Laguna, M. C. Blanco and M. C. Gimeno, Angew. Chem., Int. Ed., 2007, 46, 6184-6187.

3 Modern Gold Catalyzed Synthesis, ed. A. S. K. Hashmi and F. D. Toste, Wiley-VCH, Weinheim, 2012.

4 A. S. K. Hashmi and G. J. Hutchings, Angew. Chem., Int. Ed., 2006, 45, 7896-7936.

5 R. E. M. Brooner and R. A. Widenhoefer, Angew. Chem., Int. Ed., 2013, 52, 11714-11724.

6 R. Dorel and A. M. Echavarren, Chem. Rev., 2015, 115, 9028-9072.

7 H. Schmidbaur and A. Schier, Organometallics, 2010, 29, 2-23.

8 D. Balcells, O. Eisenstein, M. Tilset and A. Nova, Dalton Trans., 2016, 45, 5504-5513.

9 C. E. Rezsnyak, J. Autschbach, J. D. Atwood and S. Moncho, J. Coord. Chem., 2013, 66, 1153-1165.

10 N. Savjani, D.-A. Roşca, M. Schormann and M. Bochmann, Angew. Chem., Int. Ed., 2013, 52, 874-877.

11 E. Langseth, A. Nova, E. A. Tråseth, F. Rise, S. Øien, R. H. Heyn and M. Tilset, J. Am. Chem. Soc., 2014, 136, 10104-10115.

12 R. L. Harlow, J. Res. Natl. Inst. Stand. Technol., 1996, 101, 327-339.

13 A. Spek, Acta Crystallogr., Sect. D: Biol. Crystallogr., 2009, 65, 148-155.

14 E. Langseth, C. H. Görbitz, R. H. Heyn and M. Tilset, Organometallics, 2012, 31, 6567-6571.

15 D. Giardina-Papa, F. P. Intini, C. Pacifico and G. Natile, Inorg. Chem., 2013, 52, 13058-13067. 
16 D. Giardina-Papa, F. P. Intini, G. Natile and C. Pacifico, Acta Crystallogr., Sect. C: Cryst. Struct. Commun., 2012, 68, $\mathrm{m} 300-\mathrm{m} 302$.

17 T. G. Chulkova, P. V. Gushchin, M. Haukka and V. Y. Kukushkin, Inorg. Chem. Commun., 2010, 13, 580-583.

18 S. M. Sbovata, F. Bettio, C. Marzano, A. Tassan, M. Mozzon, R. Bertani, F. Benetollo and R. A. Michelin, J. Inorg. Biochem., 2008, 102, 882-891.

19 S. M. Sbovata, F. Bettio, M. Mozzon, R. Bertani, A. Venzo, F. Benetollo, R. A. Michelin, V. Gandin and C. Marzano, J. Med. Chem., 2007, 50, 4775-4784.

20 P. D. Prenzler, D. C. R. Hockless and G. A. Heath, Inorg. Chem., 1997, 36, 5845-5849.

21 R. Cini, P. A. Caputo, F. P. Intini and G. Natile, Inorg. Chem., 1995, 34, 1130-1137.

22 J. M. Casas, M. H. Chisholm, M. V. Sicilia and W. E. Streib, Polyhedron, 1991, 10, 1573-1578.

23 B. de Bruin, M. J. Boerakker, R. de Gelder, J. M. M. Smits and A. W. Gal, Angew. Chem., Int. Ed., 1999, 38, 219-222.

24 A. Venugopal, A. P. Shaw, K. W. Törnroos, R. H. Heyn and M. Tilset, Organometallics, 2011, 30, 3250-3253.

25 The synthesis, characterization, and X-ray structure of $\mathrm{Au}$ (tpy)(Me)(NCMe $)^{+} \mathrm{BF}_{4}{ }^{-}$is given in the ESI. $\dagger$

26 Y. Ito, M. Sawamura and T. Hayashi, J. Am. Chem. Soc., 1986, 108, 6405-6406.

27 Y. Ito, M. Sawamura, M. Kobayashi and T. Hayashi, Tetrahedron Lett., 1988, 29, 6321-6324.

28 Y. Ito, M. Sawamura, E. Shirakawa, K. Hayashizaki and T. Hayashi, Tetrahedron Lett., 1988, 29, 235-238.

29 A. S. K. Hashmi, J. P. Weyrauch, W. Frey and J. W. Bats, Org. Lett., 2004, 6, 4391-4394.

30 S. Doherty, J. G. Knight, A. S. K. Hashmi, C. H. Smyth, N. A. B. Ward, K. J. Robson, S. Tweedley, R. W. Harrington and W. Clegg, Organometallics, 2010, 29, 4139-4147.

31 H. von Wachenfeldt, A. V. Polukeev, N. Loganathan, F. Paulsen, P. Rose, M. Garreau, O. F. Wendt and D. Strand, Dalton Trans., 2015, 44, 5347-5353.

32 K. K.-Y. Kung, V. K.-Y. Lo, H.-M. Ko, G.-L. Li, P.-Y. Chan, K.-C. Leung, Z. Zhou, M.-Z. Wang, C.-M. Che and M.-K. Wong, Adv. Synth. Catal., 2013, 355, 2055-2070.
33 Oxazoles: Synthesis, Reactions, and Spectroscopy, Part B, ed. D. C. Palmer, John Wiley \& Sons, Inc., Hoboken, NJ, USA, 2004.

34 M. J. Frisch, G. W. Trucks, H. B. Schlegel, G. E. Scuseria, M. A. Robb, J. R. Cheeseman, G. Scalmani, V. Barone, B. Mennucci, G. A. Petersson, H. Nakatsuji, M. Caricato, X. Li, H. P. Hratchian, A. F. Izmaylov, J. Bloino, G. Zheng, J. L. Sonnenberg, M. Hada, M. Ehara, K. Toyota, R. Fukuda, J. Hasegawa, M. Ishida, T. Nakajima, Y. Honda, O. Kitao, H. Nakai, T. Vreven, J. A. Montgomery, Jr., J. E. Peralta, F. Ogliaro, M. Bearpark, J. J. Heyd, E. Brothers, K. N. Kudin, V. N. Staroverov, R. Kobayashi, J. Normand, K. Raghavachari, A. Rendell, J. C. Burant, S. S. Iyengar, J. Tomasi, M. Cossi, N. Rega, J. M. Millam, M. Klene, J. E. Knox, J. B. Cross, V. Bakken, C. Adamo, J. Jaramillo, R. Gomperts, R. E. Stratmann, O. Yazyev, A. J. Austin, R. Cammi, C. Pomelli, J. W. Ochterski, R. L. Martin, K. Morokuma, V. G. Zakrzewski, G. A. Voth, P. Salvador, J. J. Dannenberg, S. Dapprich, A. D. Daniels, Ö. Farkas, J. B. Foresman, J. V. Ortiz, J. Cioslowski and D. J. Fox, Gaussian 09, Rev. D.01, Gaussian, Inc., Wallingford CT, 2009.

35 C. Adamo and V. Barone, J. Chem. Phys., 1999, 110, 61586170.

36 S. Grimme, J. Antony, S. Ehrlich and H. Krieg, J. Chem. Phys., 2010, 132, 154104.

37 E. Langseth, M. L. Scheuermann, D. Balcells, W. Kaminsky, K. I. Goldberg, O. Eisenstein, R. H. Heyn and M. Tilset, Angew. Chem., Int. Ed., 2013, 52, 16601663.

38 R. Krishnan, J. S. Binkley, R. Seeger and J. A. Pople, J. Chem. Phys., 1980, 72, 650-654.

39 A. D. McLean and G. S. Chandler, J. Chem. Phys., 1980, 72, 5639-5648.

40 D. Figgen, G. Rauhut, M. Dolg and H. Stoll, Chem. Phys., 2005, 311, 227-244.

41 D. Figgen, K. A. Peterson, M. Dolg and H. Stoll, J. Chem. Phys., 2009, 130, 164108.

42 A. V. Marenich, C. J. Cramer and D. G. Truhlar, J. Phys. Chem. B, 2009, 113, 6378-6396. 